\title{
A COMPARISON OF LEAF CRYSTAL MACROPATTERNS IN THE TWO Sister genera Piper and Peperomia (Piperaceae) ${ }^{1}$
}

\author{
Harry T. Horner ${ }^{2,5}$, Stefan Wanke ${ }^{3}$, And Marie-StÉPhanie SAmain ${ }^{4}$
}

\author{
${ }^{2}$ Department of Genetics, Development and Cell Biology \& Microscopy and NanoImaging Facility, Iowa State University, \\ Ames, Iowa 50011-1020 USA; ${ }^{3}$ Institut für Botanik, Technische Universität Dresden 01062 Dresden, Germany; and ${ }^{4}$ Research \\ Group Spermatophytes, Department of Biology, Ghent University, K.L. Ledeganckstraat, 35, Gent, Belgium
}

- Premise of the study: This is the first large-scale study comparing leaf crystal macropatterns of the species-rich sister genera Piper and Peperomia. It focuses on identifying types of calcium oxalate crystals and their macropatterns in leaves of both genera. The Piper results are placed in a phylogenetic context to show evolutionary patterns. This information will expand knowledge about crystals and provide specific examples to help study their form and function. One example is the first-time observation of Piper crystal sand tumbling in chlorenchyma vacuoles.

- Methods: Herbarium and fresh leaves were cleared of cytoplasmic content and examined with polarizing microscopy to identify types of crystals and their macropatterns. Selected hydrated herbarium and fresh leaf punches were processed for scanning electron microscopy and x-ray elemental analysis. Vibratome sections of living Piper and Peperomia leaves were observed for anatomical features and crystal movement.

- Key results: Both genera have different leaf anatomies. Piper displays four crystal types in chlorenchyma—crystal sand, raphides, styloids, and druses, whereas Peperomia displays three types—druses, raphides, and prisms. Because of different leaf anatomies and crystal types between the genera, macropatterns are completely different. Crystal macropattern evolution in both is characterized by increasing complexity, and both may use their crystals for light gathering and reflection for efficient photosynthesis under low-intensity light environments.

- Conclusions: Both genera have different leaf anatomies, types of crystals and crystal macropatterns. Based on Piper crystals associated with photosynthetic tissues and low-intensity light, further study of their function and association with surrounding chloroplasts is warranted, especially active crystal movement.

Key words: calcium oxalate crystals; crystal movement; crystal sand; druses; leaf crystal macropatterns; Peperomia; Piper; Piperaceae; raphides; styloids.

Microscopic inorganic crystals of calcium oxalate, its soluble salts, and the free acid are common features in plant organs of the majority of angiosperms (McNair, 1932; Metcalfe and Chalk, 1957, 1983; Zindler-Frank, 1976, 1987; Nakata, 2003). They are also found in a variety of gymnosperms (Fink, 1991), ferns and fern allies (Poirault, 1893; H. T. Horner, personal communication, 2012), green algae (Pueschel, 2001; Leliaert and Coppejans, 2004; Pueschel and West, 2007), and fungi (Arnott, 1995). Collectively, the inorganic crystals occur in all plant organs and in almost every type of tissue. The crystalline form can make up from about $1 \%$ to over $90 \%$ of a plant's dry mass (Zindler-Frank, 1976, 1987; Nakata, 2003;

${ }^{1}$ Manuscript received 4 January 2012; Revision accepted 12 April 2012.

The authors thank the Curators of the Missouri Botanical Garden Herbarium (MO), St. Louis, Missouri; Duke University Herbarium (DUKE), Durham, North Carolina; the Chicago Museum of Natural History Herbarium (F), Chicago, Illinois; and especially Deborah Lewis, Curator of the Ada Hayden Herbarium (ISC), Iowa State University, Ames, for ordering and helping us to selectively remove leaf specimens for analysis; Dr. Nels Lersten, Emeritus Professor, colleague and friend, Department of Ecology, Evolution and Organismal Biology, Iowa State University for his early interests in this project; the Iowa State University Freshman Honors Program for partial support for Hana Yoon and Tiranee Ruchti; the George Washington Carver Summer Undergraduate Intern Program for partial support of Leslie Nelson; the Microscopy and NanoImaging Facility for use of its facilities; the Department of Genetics, Development and Cell Biology for partial support for H.T.H.; and the staff of the Botanical Garden of Ghent University for their support.

${ }^{5}$ Author for correspondence (hth@iastate.edu); phone: 1-515-294-8635; fax: $1-515-294-1337$

doi:10.3732/ajb.1200007
Braissant et al., 2004; Hartl et al., 2007). The literature traditionally describes five common shapes or forms of these crystals: prisms, styloids, raphides, druses, and crystal sand (Franceschi and Horner, 1980; Horner and Wagner, 1995; Franceschi and Nakata, 2005).

In that calcium oxalate (and its soluble forms) are so common in plants and fungi, the question of its physiological role has been raised from the late 1800s (see Olsen, 1939) to the present (Franceschi and Horner, 1980; Nakata, 2003; Franceschi and Nakata, 2005). Possible functions are summarized by ZindlerFrank (1976, 1987), Nakata (2003), and Franceschi and Nakata (2005), and they are generally characterized as bulk calcium regulation (binding up excess calcium or releasing it at specific physiological periods during development); removal of toxic oxalic acid; protection against herbivory; removal of heavy metals, providing strength to tissues; and concentrating and dispersing light waves (Schürhoff, 1908; Franceschi and Horner, 1980; Nakata, 2003; Franceschi and Nakata, 2005; Kuo-Huang et al., 2007). All of these possibilities have been variously discussed; however, no definitive consensus of a single function, if any, has been reached, to date. The reason for this is that plants have evolved to respond to the uptake of calcium in a variety of ways as environments have changed and, in turn, they have evolved one or more metabolic pathways to produce oxalate (Horner et al., 2000; Nakata, 2003; Franceschi and Nakata, 2005) to accommodate the storage, distribution, and use of the soluble oxalates and crystalline calcium oxalate. Crystallization results in crystals of different shapes and tissue/organ locations. The fact that crystals are most commonly found in cell vacuoles, and sometimes in the extracellular matrix, further complicates pinpointing a specific unifying function. 
Plant crystals are typically visualized by sectioning through organs to anatomically reveal the cellular/vacuolar crystals and observing them with polarizing microscopy. In some instances, especially with leaves, all cellular contents can be chemically removed while retaining only the cell walls and the inorganic crystals, again, allowing for their observation with polarizing microscopy. A number of previous studies (Frank, 1972; Lersten and Horner, 2000, 2004, 2005a, 2005b, 2006, 2007, 2008a, $2008 \mathrm{~b}, 2011$ ) have used this general method to describe the types of crystals and their locations (macropatterns) within leaves from a variety of plant groups. These studies showed that both the crystals and their macropatterns are species and genus specific and may contribute to understanding phylogenetic relationships, if not their functional significance.

Horner et al. (2009) studied the genus Peperomia (Piperaceae) in this way and found there were three types of crystal forms, their arrangements were species specific to certain tissues, and, together, they supported the concept from previous studies that crystals, as a character, may have phylogenetic significance (Lersten and Horner, 2000, 2007, 2008a, 2009, 2011; Horner et al., 2009). The sister genus Piper, which overlaps similar geographic ranges with Peperomia, was chosen in this study to determine whether the same crystal types are common to the species of both genera, whether they have common crystal macropatterns characterized by a similar evolutionary scenario, and whether Piper species have a crystal type and location within leaves, similar to the druses in Peperomia that could be involved in light gathering and reflection as suggested by Schürhoff (1908), Franceschi and Horner (1980), and Kuo-Huang et al. (2007). The fact that species of these two genera have similar geographic ranges, display different leaf anatomies (Datta and Dasgupta, 1977; Souza et al., 2004), and either are relatively small herbaceous terrestrial or epiphytic succulents (Peperomia) or larger terrestrial herbs, climbers, shrubs, and trees (Piper) add to the importance of this study (Isnard et al., 2012).

\section{MATERIALS AND METHODS}

Piper species were selected for this study from the phylogenetic tree published by Jaramillo et al. (2008) to include as many infrageneric clades recognized by these authors as possible. Sixty-three species were obtained from the following herbaria: DUKE (Duke University), F (Chicago Natural History Museum), ISC (Iowa State University), and MO (Missouri Botanical Garden) (Appendix 1). In addition, 41 species of Peperomia beyond those published in Horner et al. (2009) (Appendix 2) were collected from dried leaves from the Ghent University Botanical Garden for this study.

Leaf clearings-A multicompartment system (Horner and Arnott, 1961) was used to process the specimens (typically circular leaf punches). Herbarium leaf punches and fragments were collected from each specimen/species, hydrated in deionized water at $60^{\circ} \mathrm{C}$ overnight, and they along with punches from living greenhouse leaves (Piper kadsura, $P$. nigrum, $P$. peltatum in this study), were treated with commercial household bleach $(5.25 \%$ sodium hypochlorite) for about $24 \mathrm{~h}$, thoroughly washed in running tap water for several hours, dehydrated through an ethanol series $(25,50,70,95,100,100 \%)$ for 30 min per step, transferred to a 1:1 solution of $100 \%$ ethanol to xylene for 2 $\mathrm{h}$ and then transferred through two changes of pure xylene for several hours. The xylene-infiltrated punches were soaked in xylene-diluted Permount (http://www.fishersci.com) embedding medium and placed in stock Permount embedding medium on glass slides on a warming tray, and carefully coverslipped to prevent capture of air bubbles. Lead weights were placed on top of the coverslips to ensure flatness of the punches while the Permount dried at the coverslip edges. The cleared and mounted specimens were observed between crossed polarizers with an Olympus BH 10 compound light microscope. Digital images (Zeiss Axiocam MRc digital camera) of the leaf crystals were captured at different leaf focal planes.
Vibratome sections-To verify the anatomy of Piper leaves as published by Souza et al. (2004) and others, we cross-sectioned leaves from all three Piper species [P. nigrum (Fig. 1), P. kadsura (Fig. 2; SEM leaf fracture), and P. peltatum (Fig. 3)] growing in the ISU Bessey greenhouse with a vibratome and digitally visualized the crystals for comparison. Crystal forms were compared with many published images. Location of the crystal forms was determined by visually identifying an epidermis (adaxial or abaxial) and focusing through the cleared leaf. The sizes of the crystal forms varied, introducing interpretations for the smallest crystals (see Results).

Crystal shape and composition-To verify the shape and elemental composition of the crystals, especially the small "druses" and "styloids" (besides their birefringence between crossed polarizers), we chemically fixed leaf punches or segments of herbarium and fresh specimens in formalin-acetic acid-alcohol (FAA), and samples were then dehydrated in an ethanol series, critical-point dried, fractured to expose the internal leaf anatomy, mounted and thinly sputter coated with $10 \mathrm{~nm}$ gold-palladium (20:80), and observed with a scanning electron microscope (JEOL 5800LV SEM) in secondary electron and $\mathrm{x}$-ray modes (Lersten and Horner, 2011). Diameters of one form of crystal (druses) were measured by digitally capturing fields of the crystals in cleared leaves using an image analysis system (Horner et al., 2009).

Crystal movement-During observations of the fresh leaf cross-sections of Piper kadsura, $P$. nigrum, and P. peltatum, movement of the crystals contained in their chlorenchymas was noticed. Additional leaf cross-sections were made of these three species, along with those from Peperomia obtusifolia and P. prostrata (Bessey greenhouse; Horner et al., 2009). Time-lapse microcinematography was carried out using a Zeiss Axioplan II microscope fitted with a Zeiss MRc digital camera, polarizers, and Zeiss cinematography software. Images of the crystal sand-containing chlorenchyma from the three greenhouse-growing Piper species were captured near real time and recorded in the AVI mode for playback. One example, a static image of a Piper nigrum vibratome leaf cross section with two prominent crystal sand (CS) cells is shown in Fig. 30. The time-lapse microcinematography movie identifies the movement of the CS in Appendix S1 (see Supplemental Data with the online version of this article).

Reconstruction of character evolution using parsimony-As a backbone phylogeny to be used in character reconstruction of crystal macropatterns, we adopted the results of the to-date most comprehensive study dealing with the relationships of the genus Piper (Jaramillo et al., 2008). The Bayesian phylogenetic consensus tree from Jaramillo et al. (2008) was downloaded from the TreeBase database (http://treebase.org, S2188) and reduced in sampling to match the sampling of the present study by not altering the relationships found by Jaramillo et al. (2008). Character states for the five major crystal macropatterns (Table 1) were compiled for all species in a matrix as follows: (1) crystal sand (CS), styloids (STYL), raphides (RAPH), druses (D), and a special combination of crystal sand and styloids (CSSTYL). Forty-one of the 63 Piper species studied here have been sequenced and placed by Jaramillo et al. (2008) representing eight of 10 clades found by the authors. Availability of sequence data was the limiting factor for the sampling to be used in a character-state reconstruction approach. Evolution of the patterns was investigated by plotting the character states on the phylogenetic tree using the parsimony ancestral state reconstruction method of the program Mesquite version 2.75 (Maddison and Maddison, 2011).

TABle 1. Piper leaf crystal macropatterns of all 63 species (Table 2) in this study, including 41 species with molecular data (Fig. 38).

\begin{tabular}{lrrrrr}
\hline \hline $\begin{array}{l}\text { Five major } \\
\text { macropatterns }\end{array}$ & 63 species & \multicolumn{2}{c}{$\begin{array}{c}\text { Percentage } \\
\text { of total }\end{array}$} & 41 species & $\begin{array}{c}\text { Percentage } \\
\text { of total }\end{array}$ \\
\hline 1) CS/CS & 26 & 41.2 & 41.2 & 20 & 48.8 \\
2) CSSTYL/CSSTYL & 8 & 12.7 & 17.5 & 4 & 9.6 \\
CS/STYL & 1 & 1.6 & & & \\
CSSTYL/STYL & 1 & 1.6 & & & \\
CSSTYL/CS & 1 & 1.6 & & & \\
3) STYL/STYL & 1 & 1.6 & 4.8 & 1 & 2.4 \\
STYL/CSSTYL & 1 & 1.6 & & & \\
STYL/CS & 1 & 1.6 & & & \\
4) RAPH/RAPH & 21 & 33.3 & 33.3 & 15 & 36.6 \\
5) D/D & 2 & 3.2 & 3.2 & 1 & 2.4 \\
Total & 63 & 100 & 100 & 41 & 100 \\
\hline
\end{tabular}



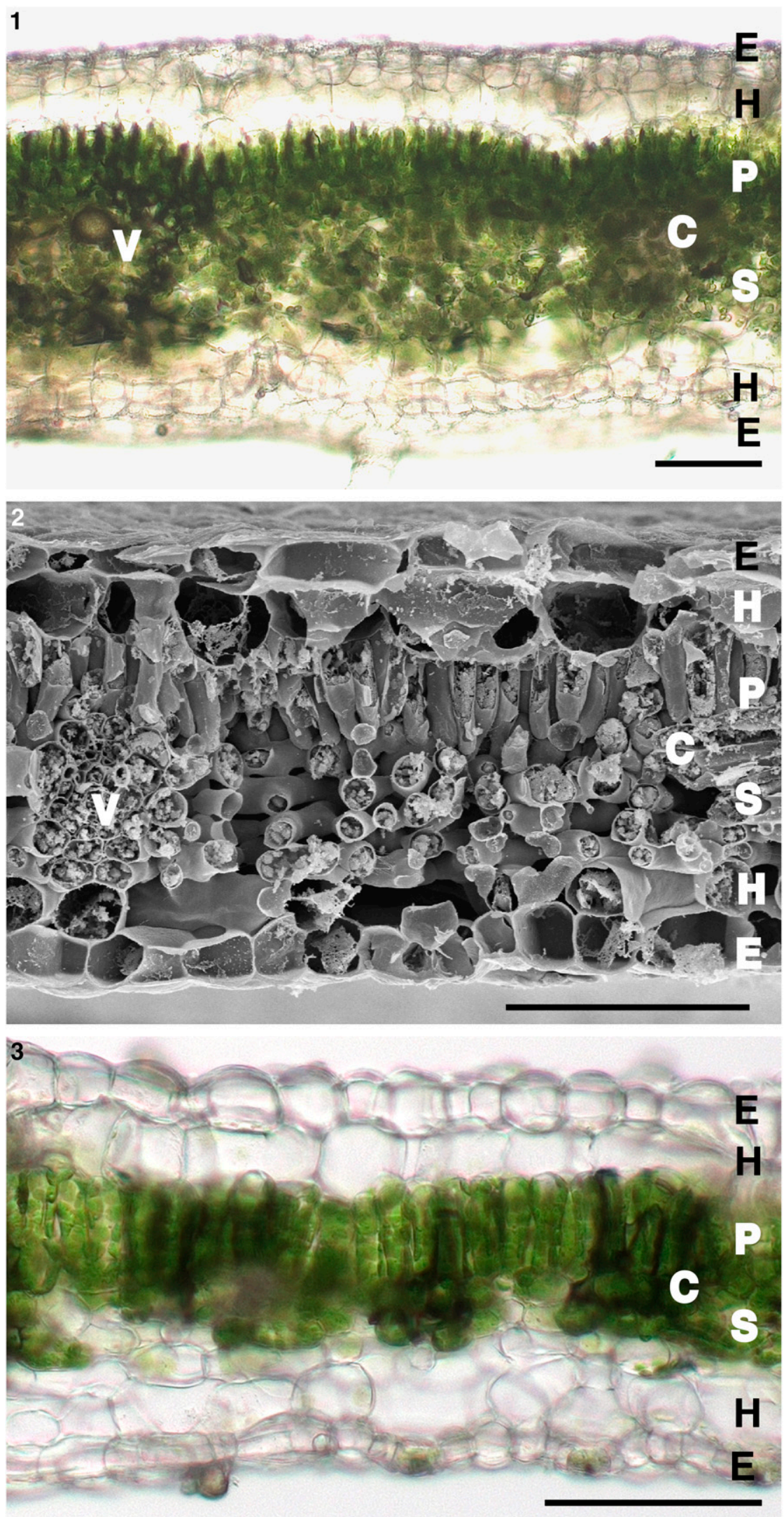

Figs. 1-3. Fresh vibratome and fixed, fractured cross sections of Piper leaves displaying single-layered epidermises (E), single-layered hypodermises $(\mathrm{H})$, chlorenchyma $(\mathrm{C})$ consisting of palisade $(\mathrm{P})$ and spongy $(\mathrm{S})$ parenchymas and venation $(\mathrm{V})$. 1. . nigrum vibratome section. 2. P. kadsura scanning electron microscope fracture. 3. $P$. peltatum vibratome section. All bars $=100 \mu \mathrm{m}$. 

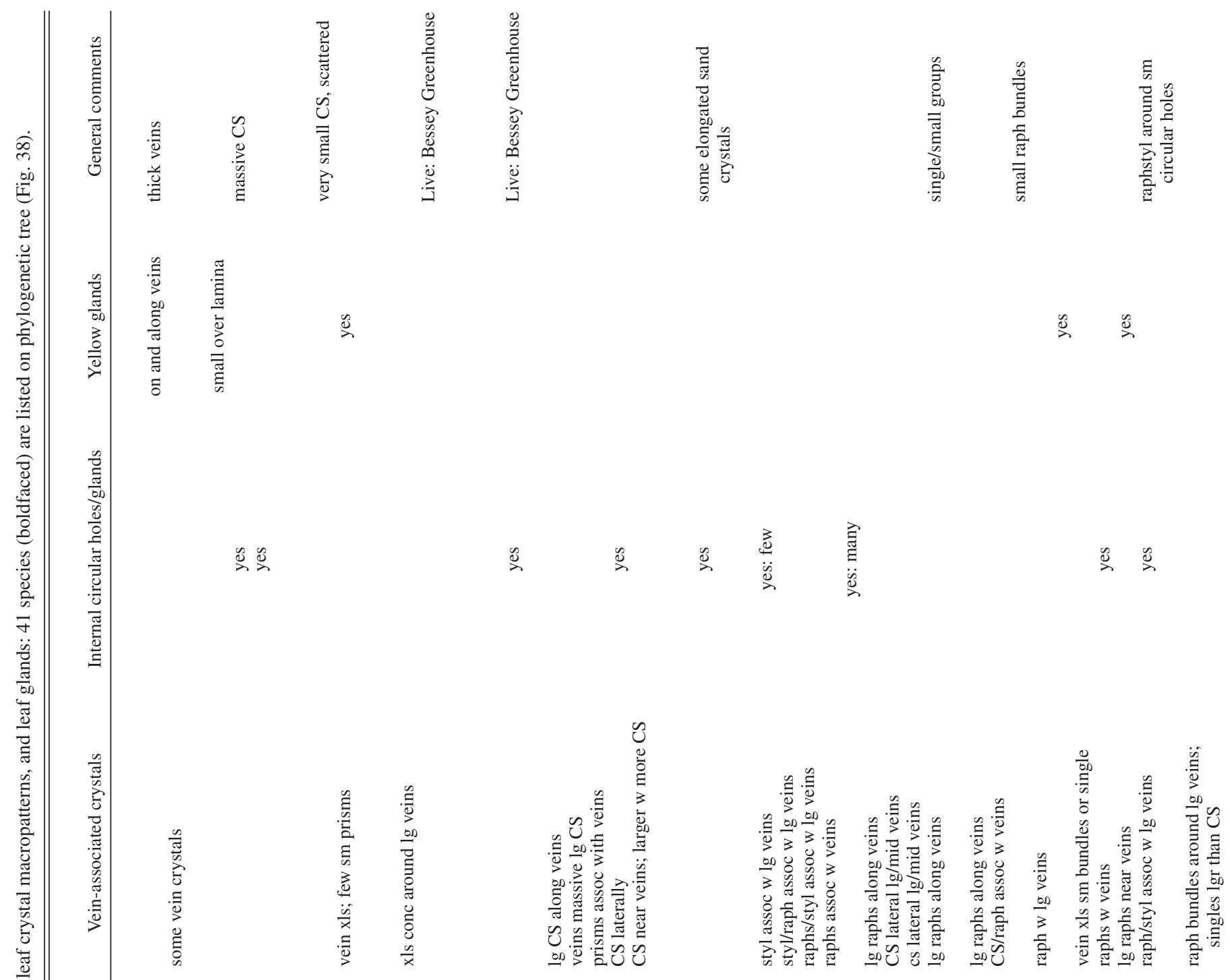

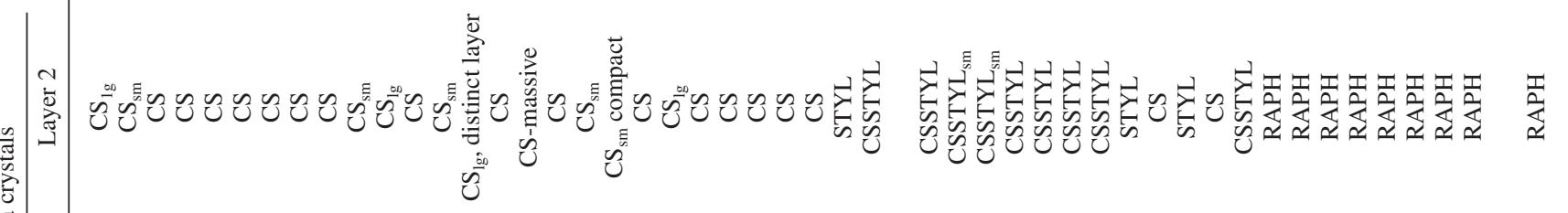

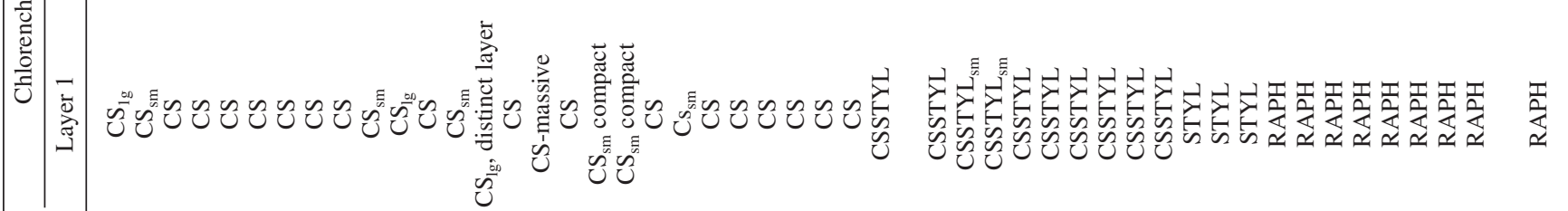




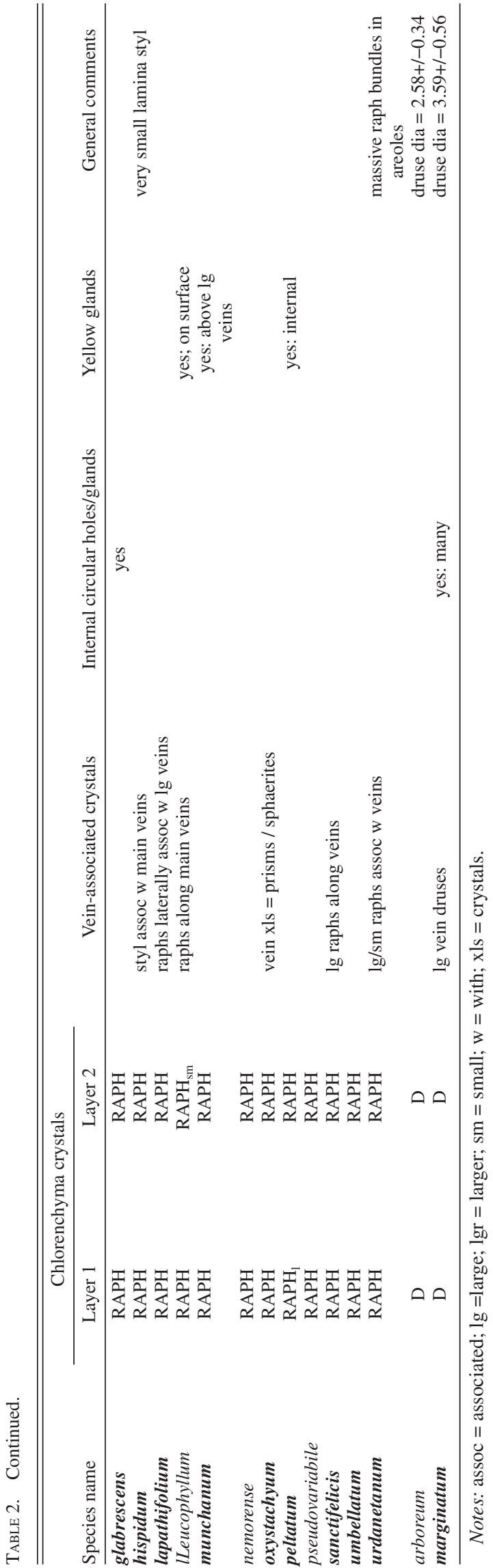

\section{RESULTS}

A total of 63 Piper species (Appendix 1, Tables 1 and 2) were analyzed in several ways to determine whether their leaves contained crystals and whether crystal macropatterns were present. The leaves consisted of what appeared to be upper and lower, typically single-layered epidermises, usually a hypodermis consisting of at least one layer interior to each epidermis, and a distinct chlorenchyma sandwiched between a layer of palisade parenchyma and a one to several layered spongy parenchyma (both layers containing chloroplasts) within which the vasculature resided (see Figs. 1-3). The relative sizes of the cells of the hypodermises and within the palisade parenchyma and spongy parenchyma varied with species, as did total leaf thickness.

Piper leaf crystal types-Leaves of all 63 species (Table 2) displayed one or more types of crystals: crystal sand (CS-P. amalago; Fig. 4), styloids (STYL-P. aduncum, Fig. 5), raphides (RAPH-P. oxystachyum; Fig. 6), druses (D-P. arboreum; Fig. 7), and (CSSTYL-P. ledebourii; Fig. 8). Styloids were defined as shorter and thicker than the needle-like raphides (long, thin, and pointed), relatively few in number per cell, and sometimes they were fairly short when in the same cell with CS. Therefore, in the latter case, the designation CSSTYL was used (Fig. 8).

$x$-ray elemental analysis of crystals-Piper leaf fractures of species containing CS-P. nigrum (Fig. 9), STYL-P. nemorense (Fig. 10), RAPH-P. oxystachyum (Fig. 11) and D-P. marginatum (Fig. 12) were analyzed for their elemental composition. All four types of crystals produced dominant spectral peaks for both calcium $(\mathrm{Ca})$ and oxygen $(\mathrm{O})$. The spectrum in Fig. 13 (P. nigrum) is representative for all four crystal types in that the peaks for $\mathrm{Ca}$ and $\mathrm{O}$ varied only slightly among the spectra. Two peaks for palladium $(\mathrm{Pd})$ and gold $(\mathrm{Au})$ represent the heavy metals used in the sputter coating and a very small peak sometimes occurred just above background for silicon (Si). Some previous publications have indicated that Piper species contain silica $\left(\mathrm{SiO}_{2}\right)$ (i.e., Gobbi, 2003). Since the leaf fractures represented exposed crystals in fractured, open cells, including cytoplasm and cell walls, the source of the Si peak, when present, was not identifiable by elemental mapping (not shown). However, if the analyzed crystals were silica, the peak spectrum and mapping would have been much different. In addition, silica does not display the birefringence of the calcium oxalate forms.

Location of leaf crystals-The different crystal types were typically confined to the chlorenchyma (palisade and spongy parenchymas) in all 63 species, and they occurred throughout the leaf lamina. They were not always associated with the veins (see Table 2), even though in some instances there was a concentration of crystals around the primary and secondary veins and they were often larger than the lamina crystals (see later). In some species, the two tissues were distinguishable from each other by having different crystal types or two different sizes of cells with the same crystal type (P. garagaranum; Table 2 ; layer 1 and layer 2; Figs. 14, 15). For instance, when CS was observed both in the palisade parenchyma and in the spongy parenchyma, a designation of CS/CS was assigned this pattern; or when CS was identified in the palisade parenchyma and STYL was identified in the spongy parenchyma, a designation for this combination of crystal types in a single leaf was assigned CS/STYL; or if the reverse occurred, the designation 

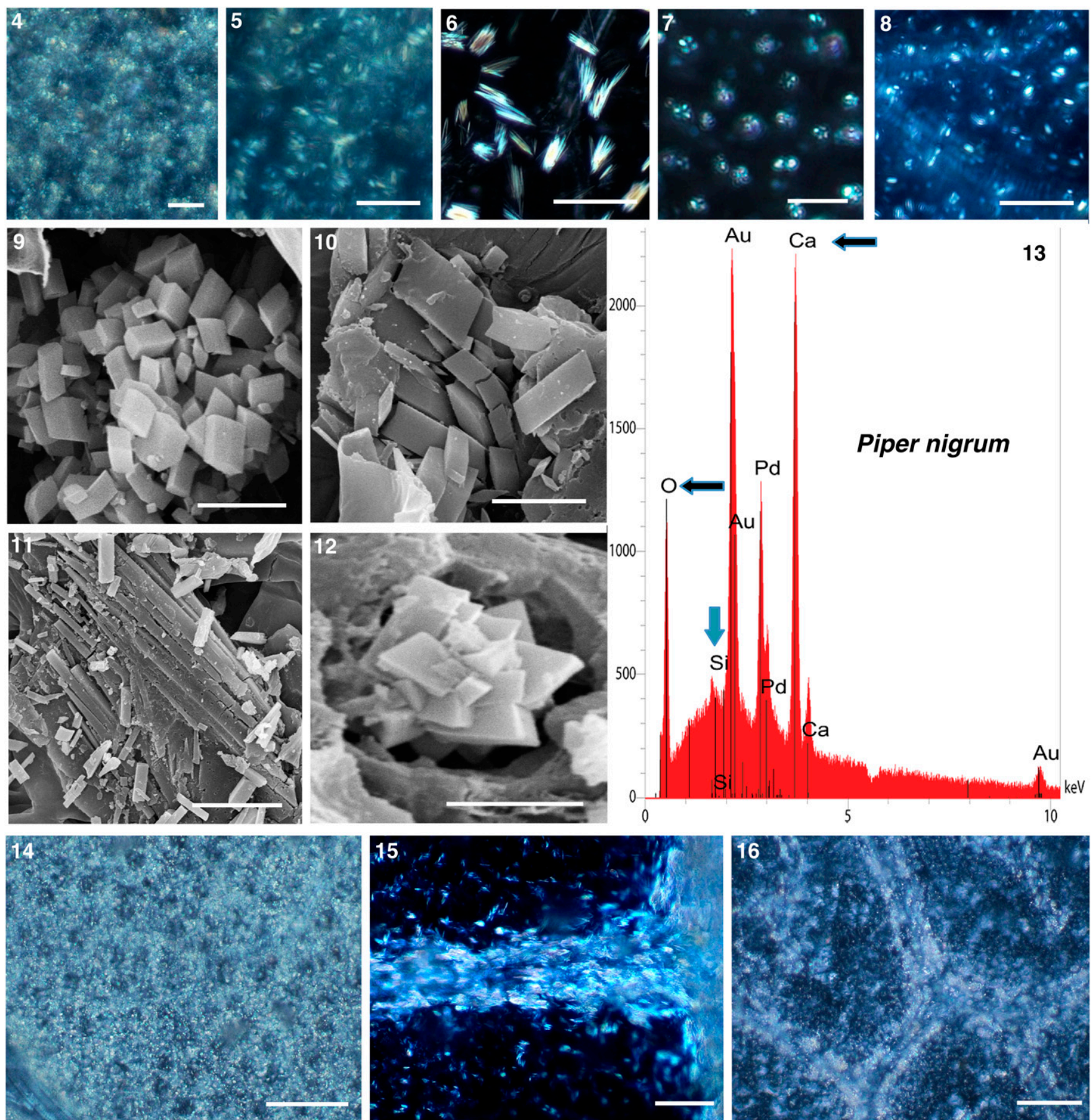

13
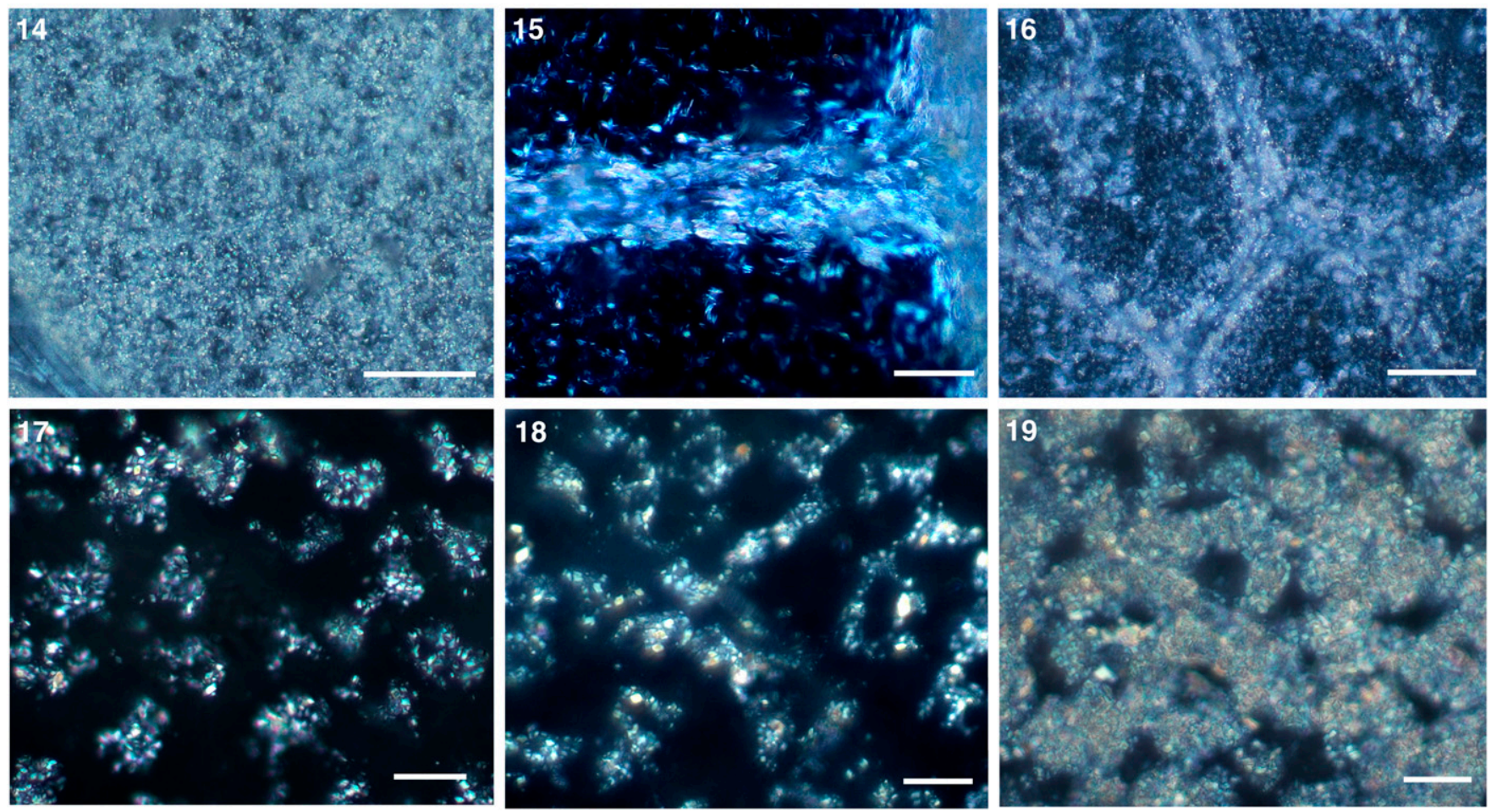
was STYL/CS. In most cases, however, the two layers could not be distinguished from each other, and there was only one crystal type present. As mentioned previously, these designations were given CS/CS, STYL/STYL, RAPH/RAPH, or D/D and are identified alphabetically by crystal type and species (Table 2).

Table 1 separates the 63 Piper species into five (1-5) major crystal macropatterns. Macropatterns 1, 4, and 5 each have only one type of crystal, whereas 2 and 3 have mixtures of two types of crystals. These mixtures are grouped into one of these two macropatterns based on the predominance of one of the two types of crystals present. The resulting five macropatterns show CS/CS $(41.2 \%)$ as the most common macropattern present among the 63 species, followed by RAPH/RAPH (33.3\%), CSSTYL mixture (17.5\%), STYL mixture (4.8\%), and D/D (3.2\%).

The 41 Piper species having molecular data (22 of the 63 species lacked data) showed the same major macropatterns and trends as the 63 species (Table 1): CS/CS (48.8\%), RAPH/ RAPH (36.6\%), CSSTYL mixture (9.6\%), STYL mixture $(2.4 \%)$, and D/D (2.4\%). Figure 38 places the 41 species on a phylogenetic tree (see Materials and Methods) to show the evolutionary relationships of the crystal macropatterns.

CS/CS macropattern-Twenty-six (41.2\%) of the 63 species had the CS/CS macropattern. It was the most common macropattern of the five (Tables 1 and 2). At least one species displayed two distinct layers of loosely arranged CS cells that were moderately packed with CS (Figs. 14, 15). Some species had chlorenchyma cells completely packed with sand crystals (Figs. 16, 19). In some cases, the crystals were concentrated around the veins (Figs. 17, RAPH; 18, CS). The CS sand cells sometimes were relatively small (CS-s) or relatively large (CS-1) and were so identified (Table 2). One species (P. korthalsii) had a combination of CS/STYL (Tables 1 and 2) and was included in the CSSTYL/CSSTYL macropattern (next section).

CSSTYL/CSSTYL macropattern-Eight (12.7\%) of the 63 species displayed crystal sand with larger, more elongated crystals associated with them that we termed styloids (Table 1 and 2). These cells were designated as CSSTYL and were either evident throughout the chlorenchyma (Tables 1 and 2; Figs. 20-23) or were associated with another crystal type of either CSSTYL/ STYL (Fig. 20) or CSSTYL/CS (Figs. 21-23). These macropatterns were represented by two species, $P$. jaliscanum and $P$. medium, respectively.

STYL/STYL and mix-Three (4.8\%) of the 63 species displayed styloids throughout the chlorenchyma or a mixture of STYL and CS, patterns different than what was included in the previous macropattern (Tables 1 and 2).

RAPH/RAPH macropattern-Twenty-one (33.3\%) of the 63 species displayed only raphides (RAPH) (Tables 1 and 2). In some species, the raphides (as bundles) were small and relatively sparse (Fig. 24) or large and numerous (Fig. 25). Often it was impossible to determine whether the individual raphides were pointed or ridged at their ends unless observed with SEM.

D/D macropattern-Two species (3.2\%) of the 63 species displayed very small druses (D) with medium diameters of 3.57 $\mu \mathrm{m} \pm 0.34 \mu \mathrm{m}$ (Fig. 26; P. marginatum) and $2.58 \mu \mathrm{m} \pm 0.56 \mu \mathrm{m}$ (Fig. 27; P. arboreum) (Table 2). Their diameters were at the smallest end of the range of all of the Peperomia species (range $27.97 \pm 4.07$ to $3.12 \pm 0.89$; Horner et al., 2009 and included Table 2). Leaf fractures of these two species confirmed the LM polarized images that the "druses" are, in fact, very small druses consisting of a spherical array of crystals, each with several facets (Fig. 12; P. marginatum).

Leaf surface circular yellow glands and interior lamina circular clear regions-Both yellow glands (8 of 63 species) (Figs. 20, 28 ) and interior laminar, circular, clear regions (11 of 63 species) (Fig. 29) were observed associated with leaves of some of the Piper species (Table 2). The yellow glands did not appear to have any association with the crystals within the lamina. The interior, circular, clear regions could not be identified as to their glandular nature. When present, they appeared transparent in the cleared leaves with lamina crystals surrounding them but not inside. As Table 2 indicates, these two types of structures never occurred together in leaves of the same species.

Summarizing crystal macropatterns of 63 Piper speciesTable 1 summarizes five Piper crystal macropatterns from the 63 species studied. Three macropatterns $(1,4$, and 5) are distinct and contain only one type of crystal. Two separate macropatterns (2 and 3) have been identified to include combinations containing CS and STYL. These two different crystal forms appear to be more similar than dissimilar; therefore, they are included as shown, and together they represent $22.3 \%$ of the macropatterns.

Summarizing additional leaf crystal macropatterns of 41 Peperomia species-These results consistently show the presence of only druses in all palisade parenchyma cells (U) or only in palisade parenchyma cells above the veins (R) (Horner et al., 2009). In a number of species, the druses are larger in palisade parenchyma cells over the veins and smaller in similar cells associated with the areoles $\left(\mathrm{UV}_{\mathrm{big}} \mathrm{A}_{\mathrm{sm}}\right)$. Together, druses are the only type of crystal in the palisade parenchyma. Some of these species had either raphides (+/-) or prisms $(-/+)$ in the subtending spongy parenchyma.

Forty-two species of Peperomia (Table 3), not available at the time of the earlier study (Horner et al., 2009), show one species without crystals and 41 species with the same basic types of crystals as previously published (druses, raphides, and prisms) and five (U-/-, Fig. 31; U-/+, Fig. 32; U+/-,

Figs. 4-19. Piper cleared leaf specimens viewed between crossed polarizers (POL) showing types of crystals and macropatterns, fractured leaves with different crystal types exposed with scanning electron microscopy (SEM), and x-ray microanalysis of exposed crystal types. 4. POL CS in P. amalago. 5. POL STYL in P. aduncum. 6. POL RAPH in P. oxystachyum. 7. POL D in P. arboretum. 8. POL CSSTYL in P. ledebourii. 9. SEM CS in P. nigrum. 10. SEM STYL in $P$. nemorense. 11. SEM RAPH in P. oxystachyum. 12. SEM D in P. marginatum. 13. SEM x-ray elemental analysis of $P$. nigrum CS that is a representative spectrum for the other four types of crystals. Black arrows identify the prominent calcium $(\mathrm{Ca})$ and oxygen $(\mathrm{O})$ peaks; green arrow equals minor silicon ( $\mathrm{Si}$ ) peak; other two peaks are the metal mixture of gold (Au) and palladium (Pd) coating the specimen. 14. POL CS in P. garagaranum showing distinct layer $1 ; 15$. POL CS in $P$. garagaranum showing distinct layer $2 ; 16$. POL packed CS in $P$. berlandieri; 17. POL large RAPH concentrated around vascular bundle in $P$. sanctifilicis; 18. POL large CS concentrated around vascular bundles in P. penninerve; 19. POL massive CS in P. martensianum. Bars: Figs. 4, 5, 8, 14, 15, $19=20 \mu \mathrm{m}$; Figs. 6, 16-18 $=100 \mu \mathrm{m}$; Fig. $7=15 \mu \mathrm{m}$; Fig. $9=2.5 \mu \mathrm{m}$; Fig. $12=2 \mu \mathrm{m}$; Figs. 10 , $11=5 \mu \mathrm{m}$. 

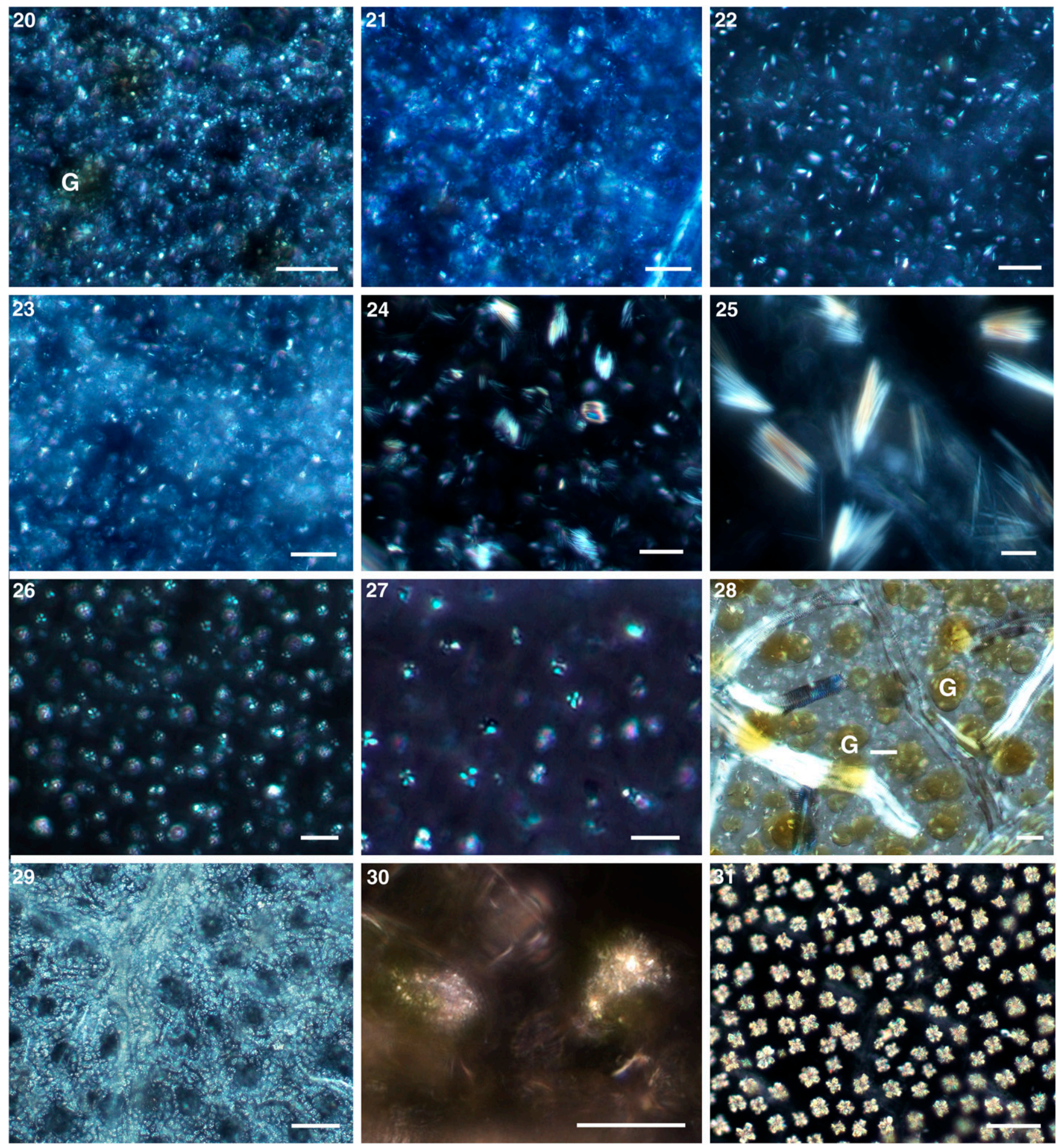

Figs. 20-31. Piper (Figs. 20-30) and Peperomia (Fig. 31) cleared leaf specimens viewed between crossed polarizers (POL) showing types of crystals, crystal macropatterns, yellow glands and internal circular regions. 20. POL CSSTYL/STYL in P. bavinum and yellow glands (G). 21. POL CSSTYL/CS in $P$. korthalsii. 22. POL CSSTYL/CS in P. jaliscanum. 23. POL CSSTYL/CS in $P$. medium. 24. POL RAPH relatively small and sparse in $P$. pseudovariabile. 25. POL RAPH relatively large and numerous in $P$. oxystachyum. 26. POL D average diameter $3.57 \mu \mathrm{m}$ in $P$. marginatum. 27. POL D average diameter $2.58 \mu \mathrm{m}$ in P. arboreum (this magnification higher than Fig 26). 28. Partial POL showing leaf yellow glands (G) in $P$. munchanum. 29. POL CS with densely packed cs cells and lamina circular regions in $P$. boehmeriifolium. 30. P. nigrum cinematography movie still showing two CS cells whose CS tumbles when illuminated with visible light (online Appendix S1); 31. P. cardenasii with U-/- macropattern. Bars: Figs. $20-25=20 \mu$ m; Figs. 26, $27=10 \mu \mathrm{m}$; Fig. $28=50 \mu \mathrm{m}$; Fig. $29=100 \mu \mathrm{m}$; Figs. $30,31=25 \mu \mathrm{m}$. 
TABle 3. Forty-two Peperomia species leaf macropatterns not included in Horner et al. (2009). Macropattern designations are given in two ways (see Results). Clade names follow Samain et al. (2009).

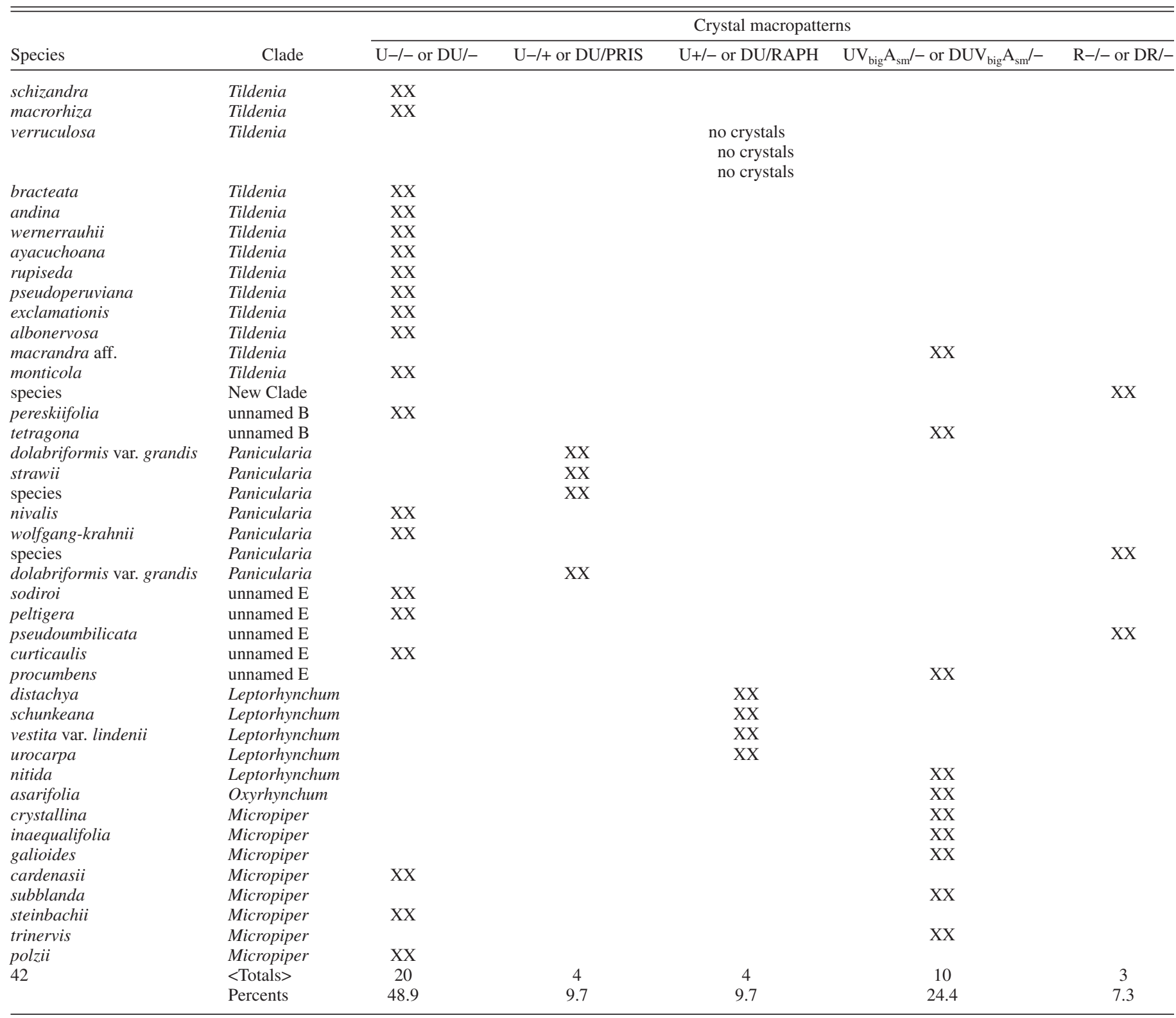

Figs. 33, 34; $\mathrm{UV}_{\mathrm{big}} \mathrm{A}_{\mathrm{sm}}-/-$, Figs. 35, 36; R-/-, Fig. 37) of the original seven macropatterns $\left(\mathrm{U}-/-, \mathrm{U}-/+, \mathrm{U}+/-, \mathrm{UV}_{\text {under }}+/-\right.$, $\mathrm{UV}_{\mathrm{big}} \mathrm{A}_{\mathrm{sm}}-/-, \mathrm{R}-/-, \mathrm{R}-/+$ ) (Horner et al., 2009). Only $\mathrm{UV}_{\text {under }}+/-$ and $\mathrm{R}-/+$ are not represented.

Of the 42 species in this study, $P$. verruculosa (Peperomia subg. Tildenia) lacked crystals. Forty-one species displaying the five macropatterns have a distribution as follows: $\mathrm{U}-/-=20$ (48.9\%); U-/+ = 4 (9.7\%); U+/- = $4(9.7 \%) ; \mathrm{UV}_{\mathrm{big}} \mathrm{A}_{\mathrm{sm}}-/-=10$ $(24.4 \%)$; and $\mathrm{R}-1-=3(7.3 \%)$. These data, when added to the data from Horner et al. (2009), show a total of 87 species studied, with two species lacking crystals altogether $(P$. dolabella and $P$. verruculosa, both in Peperomia subg. Tildenia), and the remaining 85 species display seven crystal macropatterns for a combined distribution as follows: U-/ $=85(49.4 \%)$; U-/+ = $7(8.2 \%) ; \mathrm{U}+/-=7(8.2 \%) ; \mathrm{UV}_{\text {under }}+/-=3(3.6 \%) ; \mathrm{UV}_{\mathrm{big}} \mathrm{A}_{\mathrm{sm}}-/-=$ $15(17.6 \%) ; \mathrm{R}-/-=10(11.8 \%) ;$ and $\mathrm{R}-/+=1(1.2 \%)$.
To make the macropattern character designations and scoring similar between the Peperomia and Piper results in this study and those already published for Peperomia, we use the following cross references for Peperomia: $\mathrm{U}-/-=\mathrm{DU} /-$; $\mathrm{U}+/-=$ DU/RAPH; U-/+ = DU/PRIS (= prism); $\mathrm{UV}_{\mathrm{big}} \mathrm{A}_{\mathrm{sm}}-/-=$ $\mathrm{DUV}_{\mathrm{big}} \mathrm{A}_{\mathrm{sm}}-/-; \mathrm{R}-/-=\mathrm{DR} /-; \mathrm{R}+/-=\mathrm{DR} / \mathrm{RAPH} ; \mathrm{R}-/+=$ DR/PRIS (where DU stands for druse uniformly distributed in palisade parenchyma and DR stands for druses only over the veins in the palisade parenchyma). See Table 3 for both designations.

Crystal movement-All three greenhouse-grown Piper species ( $P$. kadsura, $P$. nigrum, and $P$. peltatum) chlorenchyma cells contained CS. When the 40-45 $\mu$ m thick, water-mounted vibratome sections were exposed to varying intensities of transmitted white light on a microscope stage and viewed between 

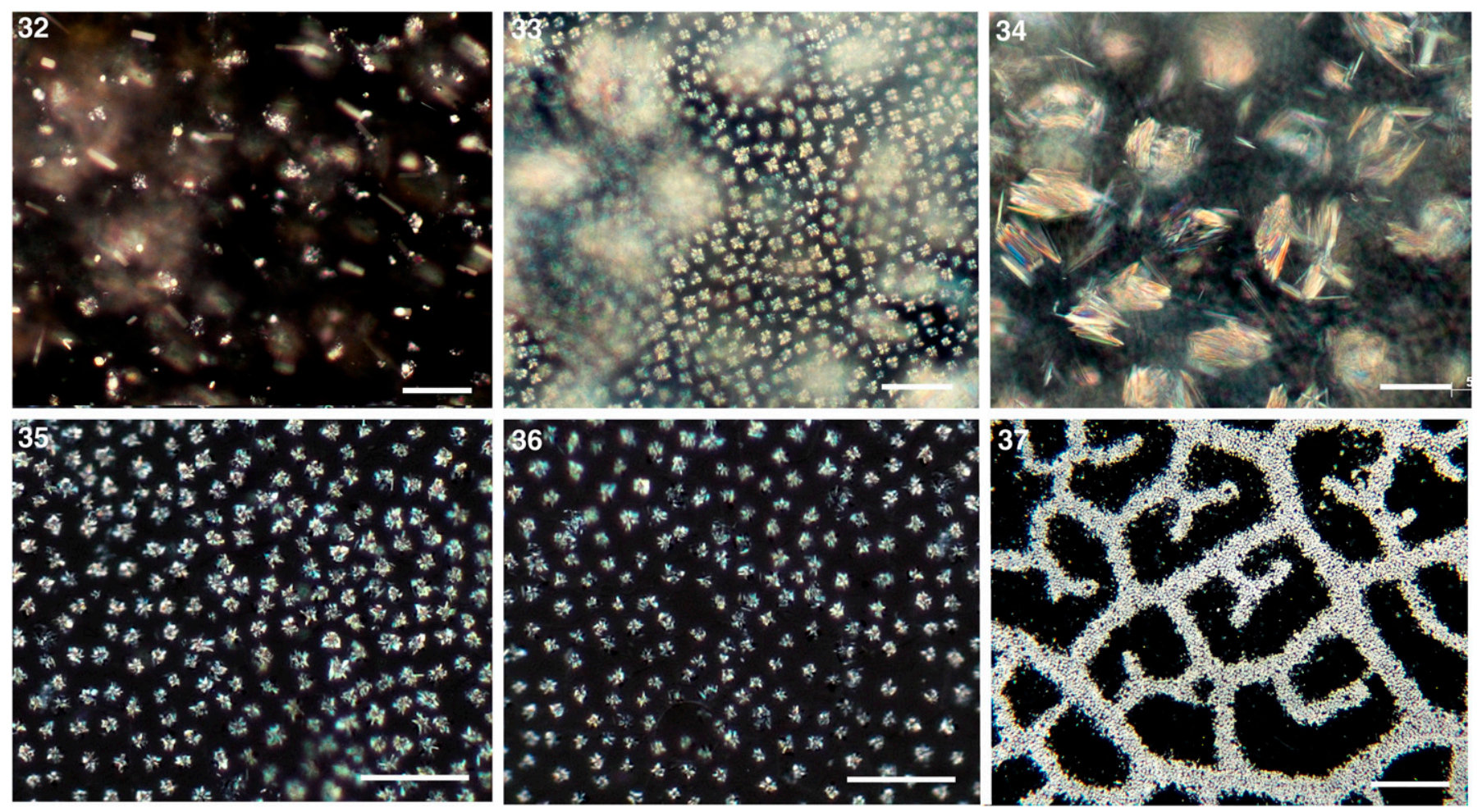

Figs. 32-37. Peperomia cleared leaf specimens viewed between crossed polarizers (POL) showing three types of crystals (druses, raphides, and prisms) and four crystal macropatterns as explained in Results. 32. P. dolabriformis var. grandis with $\mathrm{U}-/+$ macropattern. 33. $P$. urocarpa with U+/- macropattern, upper layer D. 34. P. urocarpa with U+/- macropattern, lower layer RAPH. 35. P. asarifolia with UVbigAsm-/- macropattern, larger D over veins. 36. P. asarifolia with UVbigAsm-/- macropattern, smaller D over areoles. 37. P. pseudoumbilicata with R-/- macropattern. Bars: Figs. $32-34=50 \mu$; Figs. 35, $36=100 \mu \mathrm{m}$; Fig. $37=500 \mu \mathrm{m}$.

crossed polarizers, the CS in the cells actively moved or tumbled (Fig. 30; online Appendix S1). This movement was compared with free CS from broken cells at the edge of the sections. This latter "free" CS vibrated and demonstrated what appeared to be Brownian movement. The active, tumbling movement of CS in the vacuoles of the intact chlorenchyma cells of all three species was recorded using a 6-s microcinematography clip in the AVI mode (Appendix S1, separate movie file playable with QuickTime or VLC players). The CS-containing vacuoles were surrounded by green chloroplasts. Similar leaf sections of Peperomia obtusifolia and P. prostrata were viewed with the same optical setup, but no active movement of the druses was observed in their palisade parenchyma cells. Active movement of vacuolar crystals in higher plants, to our knowledge, has not been shown before.

\section{DISCUSSION}

The significant findings of this combined Piper and Peperomia leaf crystal macropattern study are the following. We reaffirm that the leaf anatomies between the species of the two genera differ (Metcalfe and Chalk, 1957; Souza et al., 2004; Horner et al., 2009). Piper contains four types of crystals (this study; most common to least common $=\mathrm{CS}$, RAPH, STYL, and D), whereas Peperomia contains three types of crystals (most common to least common $=\mathrm{D}, \mathrm{RAPH}$, and prisms) (Horner et al., 2009). The crystal macropatterns and arrangement of crystal types in different tissues are distinctly different based on leaf anatomy; the crystal macropattern evolution in both genera is generally characterized by a similar increasing complexity. And finally, all types of crystals in both genera seem to consist of calcium oxalate. The RAPH were commonly observed in species of both genera (Piper $=33.3 \%$ and Peperomia $=13.0 \%$, whereas D was least common and very small in Piper (3.2\%) but dominant, universal, and typically much larger in Peperomia (100\%).

Piper CS and STYL, the latter sometimes being included within the crystal sand cells, are the most prevalent types occurring throughout the chlorenchyma (palisade and spongy parenchymas) (63.5\% of the 63 species studied) (Table 1). The combination of these two types of crystals occurring within one cell has been previously published (see Lersten and Horner, 2011 and other references therein); D was commonly shown to occur along with CS in species of the Naucleeae (Rubiaceae). Such examples suggest that individual crystal cells are capable of genetically producing two crystal forms. The significance of this is not understood, but it does provide an anatomical marker in the species in which it occurs.

Identification of the types of crystal observed in this study of 63 Piper species was based on one identified collection per species; there were several species where two or more collections were observed, and they consistently showed the same crystal type(s) for that species. However, there are some differences reported in the literature as to the type and composition of crystals found. For instance, Metcalfe and Chalk (1957) reported CS in P. betle (this study identified RAPH); and Gobbi (2003) found granulated silica crystals in P. amalago (this study identified 
CS, but no x-ray analysis was carried out due to a paucity of material) and RAPH in P. arboreum (this study identified D) and $P$. crassinervium (specimens not available). These conflicting results are problematic and need to be resolved by observing more collections of these species in question and ensuring the correct identification of the specimens.

In this study, polarizing microscopy was carried out on all of the Piper and Peperomia species crystals, and x-ray microanalysis on several Piper crystals. Our results show that all four (CS, RAPH, STYL, and D) crystal forms are composed of calcium oxalate. In some reports, silica has been found to be associated with cell walls. This could be the case in Piper. Some of the spectra showed a minor Si peak, but there was no specific mapping to the crystals. However, these results do not preclude the possibility that some of the species not analyzed could have silica sand. Another study will have to be conducted to pursue this possibility.

Following the optimization of the patterns on the phylogenetic tree, an evolutionary trend becomes apparent (Fig. 38). The ancestral character state of the crystal macropattern in Piper is CS, which is also the most prevalent pattern in the sampled species (Table 1; $41.2 \%$ and $48.8 \%$, respectively). Evolution within Piper is characterized by an increasing complexity, with CS in the majority of the species in the first branching clades (Macropiper, Piper, Ottonia, P. cinereum/ P. sanctum, Enckea, Peltobryon, and Pothomorphe; clade names according to Jaramillo et al., 2008) and only the last branching clade Radula being mainly characterized by the presence of both RAPH and CSSTYL, with one reversal to $\mathrm{CS}$. In each of the first branching clades, one or more species are characterized by either CSSTYL, STYL, and RAPH or D. Although crystal macropatterns of Piper and Peperomia are very distinct, it is remarkable that both genera show an increasing complexity, respectively, in crystal types and in distribution of different crystal types, demonstrating that crystal development within specific genera might be prone to adaptation to specific functions and/or conditions. In contrast to Peperomia where a slight systematical pattern of the leaf crystal macropatterns was found, they do not show any systematic value in Piper.

The underlying factor(s) controlling the type of crystal formed in any plant is still unknown, but most certainly it must be one or a combination of genetics, environmental conditions, and/or nutrient availability (Nakata and McConn, 2007). In members of the Rubiaceae, Lersten and Horner (2011) described species in which the same crystal cell contained both CS and D. It is known that $\mathrm{D}$ is an aggregate of small individual crystals held together by a common nucleation center (Horner and Wagner, 1980; Wagner, 1983), whereas CS consists of small individual tetrahedral crystals (Cody and Horner, 1985; Franceschi, 1984). In this study, Piper displays CS as its basic crystal type, and Peperomia displays D as its basic crystal type. However, no species in either genus had crystal cells with both CS and D, even though the combination of CSSTYL was a common feature in Piper. The possibility is that these two genera have diverged enough from each other so that there are no ancestral species that display intermediate forms. Small genera such as Verhuellia, Maenika, and Zippelia have yet to be studied and may provide insight to this question.

The unique observation that Piper CS and CSSTYL actively tumble in the vacuoles of chlorenchyma cells is of great interest (Fig. 30; online Appendix S1). Whether this same phenomenon holds true for the RAPH- and D-containing Piper cells will be determined when living material becomes available. In Pepero- mia, the vacuolar druses contained in the palisade parenchyma beneath a multiple hypodermis have been implicated in gathering and reflecting light to the chloroplasts surrounding them (Kuo-Huang et al., 2007; Horner, 2012). However, the Peperomia druses did not seem to actively respond to visible light in vibratome sections by moving up and down in the elongated cell vacuoles surrounded by chloroplasts, as the CS did in Piper. This may be due to the fact that only Peperomia cross sections of the leaves were observed where the length of the palisade cells are perpendicular to the beam of light, instead of along the long axis, which would be the normal orientation in leaves on the plant. Light gradients in these cells could affect movement. Observations of chemically fixed leaves do show that the druses occur in different regions of the cell vacuoles (Franceschi and Horner, 1980; Kuo-Huang et al., 2007; Horner, 2012), suggesting the druses are able to move vertically. In Piper, the orientation to the beam of light may not be important as the CS fills the vacuoles, so only tumbling and not directional movement was observed. Further experiments need to be designed to determine whether the direction of light is important in Peperomia and whether different color bands of the visible spectrum play a role in crystal movement in both genera. A further question to be answered is what is the role of the other types of crystals (especially the raphides) that occur in adjacent leaf tissues or solely in a leaf. One possibility is they may serve as further collecting and reflecting units that also direct or inhibit the light reaching the chloroplasts. Such ideas are tantalizing but still speculative at this point.

In this latter regard, a number of previous studies on species in the genus Piper (Williams et al., 1989; Chazdon and Kaufmann, 1993; see others cited therein) focused on their growing habits under variable light intensities to determine how leaf structure, leaf longevity, carbon gain, and photosynthetic capacity were affected. None of these studies included any mention of the formation and presence of calcium oxalate, even though Williams et al. (1989) indicated that long-lived leaves (i.e., P. aequale and P. lapathifolium; see Table 2) invest more in protective structures and compounds than do short-lived species ( $P$. peltatum, $P$. auritum, $P$. umbellatum; see Table 2 ) and two additional species ( $P$. hispidum, P. amalago; see Table 2) that are habitat generalists. These studies indicate that leaf construction costs to carbon gain are related to leaf longevity; i.e., strong light conditions are associated with shorter leaf longevity and greater construction costs. Chazdon and Kaufmann (1993) observed that $P$. sanctifelicis (growing under high light conditions; see Table 2) and $P$. arieianum (growing under low light conditions; see Table 2) showed light-dependent variations in total leaf thickness and leaf mass per unit area. However, when comparing photosynthetic capacity to leaf anatomy, there was a positive correlation with $P$. sanctifelicis, and much less so with $P$. arieianum. These results are interpreted to suggest the variability of the abilities of these two species to modify their physiology, metabolism, and leaf construction.

Eight of the nine species in these two latter studies were included in the present study ( $P$. aequale not included) and displayed either CS or RAPH in their chlorenchyma. Both types of crystals occurred in species growing under highlight and low-light conditions. How these crystals may be involved in the physiology and metabolism of these leaves is unknown at this time. However, increasing chlorenchyma cells containing crystals in low-light conditions and reducing chlorenchyma cells in high-light conditions could play an 


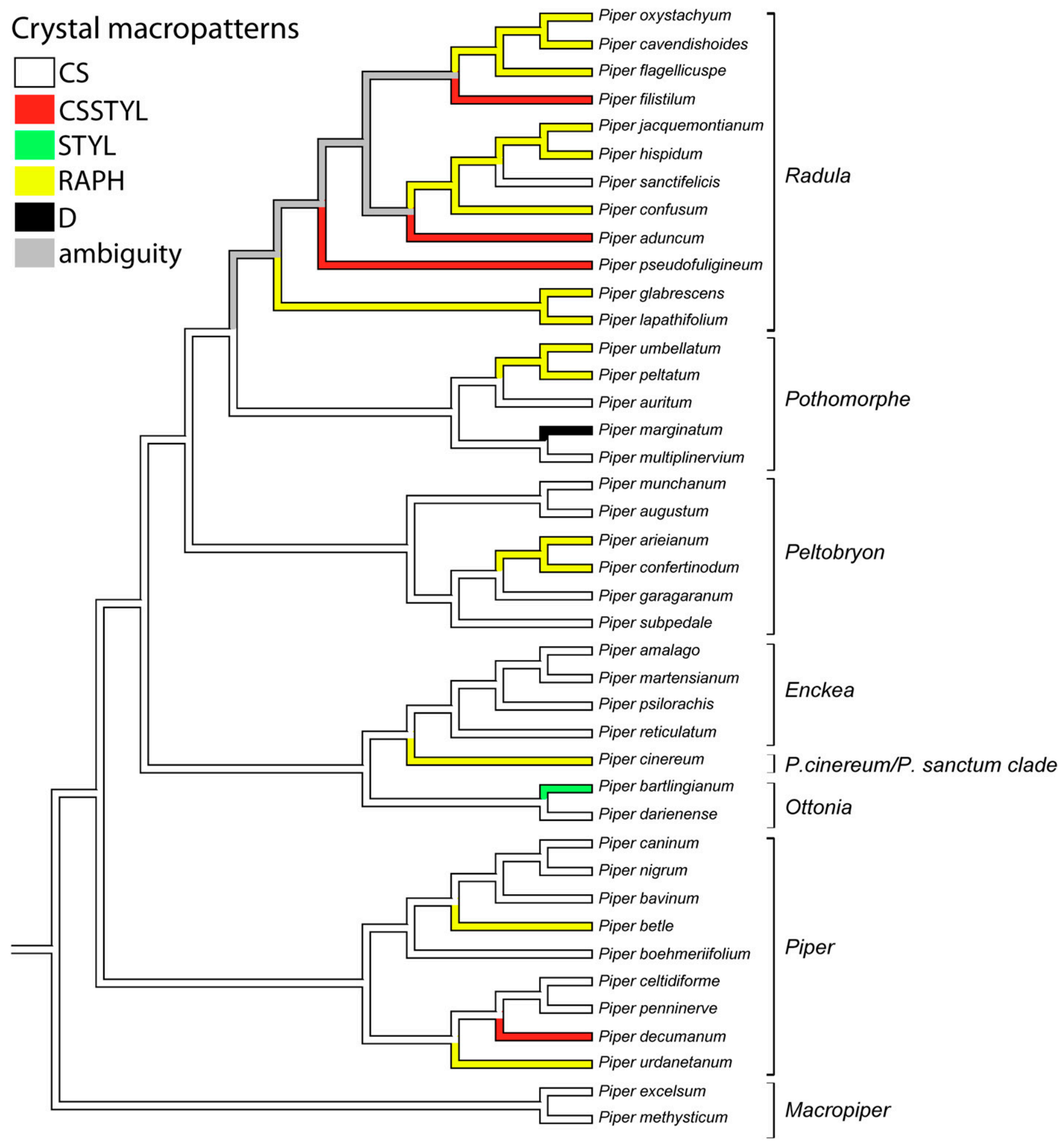

Fig. 38. Phylogenetic tree showing types of crystals (CS, CSSTYL, RAPH, and D) and their leaf macropatterns for 41 species of Piper.

important role in photosynthetic activity based on reflectivity of the crystals. It would be valuable to make these comparisons in future studies to shed light on how photosynthetic tissues producing crystals use them (number and shape) to affect photosynthetic efficiency.

In summary, this study provides new information about leaf crystal macropatterns, types of crystals, and their evolution in the genus Piper; adds additional, new and related comparative information in Peperomia; for the first time, describes active movement of crystals exposed to light in Piper leaf chlorenchyma; and provides some insights and suggestions for future studies that could help to better understand the presence and potential function of how plant organs and tissues have adapted these crystals for specific uses. 


\section{LITERATURE CITED}

Arnott, H. J. 1995. Calcium oxalate in fungi. In S. R. Khan [ed.], Calcium oxalate in biological systems, 73-111. CRC Press, Boca Raton, Florida, USA.

Braissant, O., C. Guillaume, M. Aragno, and E. P. Verrecchia. 2004. Biologically induced mineralization in the tree Milicia excelsa (Moraceae): Its causes and consequences to the environment. Geobiology 2: 59-66.

Chazdon, R. L., And S. Kaufmann. 1993. Plasticity of leaf anatomy of two rain forest shrubs in relation to photosynthetic light acclimation. Functional Ecology 7: 385-394.

Cody, A. M., AND H. T. Horner. 1985. Analytical resolution of the crystalline sand pyramids. American Journal of Botany 72: $1149-1158$.

Datta, P. C., and A. Dasgupta. 1977. Comparison of vegetative anatomy of Piperales. II. Leaves. Acta Biologica Academiae Scientiarum Hungaricae 28: 97-110.

FINK, S. 1991. Comparative microscopical studies on the patterns of calcium oxalate distribution in the needles of various conifer species. Botanica Acta 104: 306-315.

Franceschi, V. R. 1984. Developmental features of calcium oxalate crystal sand deposition in Beta vulgaris L. leaves. Protoplasma 120: 216-223.

Franceschi, V. R., ANd H. T. Horner JR. 1980. Calcium oxalate crystals in plants. Botanical Review 46: 361-427.

Franceschi, V. R., AND P. A. NAKata. 2005. Calcium oxalate in plants: Formation and function. Annual Review of Plant Biology 56: 41-71.

FRANK, E. 1972. The formation of crystal idioblasts in Canavalia ensiformis DC. at different levels of calcium supply. Zeitschrift für Pflanzenphysiologie 67: 350-358.

GoвBI, A. P. 2003. Morfo-anatomia comparative da folha de três espécies da familia Piperaceae. Monografia. Universidade Estadual de Maringá, Maringá, Brazil.

Hartl, W. P., H. Klapper, B. Barbier, H. J. Ensikat, R. Dronskowski, P. Müller, G. Ostendorp, et AL. 2007. Diversity of calcium oxalate crystals in Cactaceae. Canadian Journal of Botany 85: 501-517.

Horner, H. T. 2012. Unusual pit fields in lowermost hypodermal cell walls and uppermost walls of photosynthetic crystal-containing palisade parenchyma cells in Peperomia obtusifolia leaves. Annals of Botany doi: 10.1093/aob/mcs074.

Horner, H. T., AND H. J. ARnotT. 1961. The use of a multiple-compartment tray for processing many specimens at one time. Stain Technology 36: 204-205.

Horner, H. T., A. P. Kausch, and B. L. Wagner. 2000. Ascorbic acid: A precursor of oxalate in crystal idioblasts of Yucca torreyi in liquid root culture. International Journal of Plant Sciences 161: 861-868.

Horner, H. T. JR., AND B. L. WAGNER. 1980. The association of druse crystals with the developing stomium of Capsicum annиит (Solanaceae) anthers. American Journal of Botany 67: 1347-1360.

Horner, H. T., AND B. L. Wagner. 1995. Calcium oxalate formation in higher plants. In S. R. Khan [ed.], Calcium oxalate in biological systems, 53-72. CRC Press, Boca Raton, Florida, USA.

Horner, H. T., S. Wanke, and M.-S. SAmain. 2009. Evolution and systematic value of leaf crystal macropatterns in the genus Peperomia (Piperaceae). International Journal of Plant Sciences 170: 343-354.

Isnard, S., J. Prosperi, S. Wanke, S. T. Wagner, M.-S. Samain, S. Trueba, L. FrenzKe, et Al. 2012. Growth form evolution in Piperales and its relevance for understanding angiosperm diversification: an integrative approach combining plant architecture, anatomy, and biomechanics. International Journal of Plant Sciences 173: 1-31.

Jaramillo, M. A., R. Callejas, C. Davidson, J. F. Smith, A. Stevens, AND E. J. Tepe. 2008. A phylogeny of the tropical genus Piper using ITS and the chloroplast intron psbJ-petA. Systematic Botany 33: 647-660.

Kuo-Huang, L.-L., M. S. B. Ku, and V. R. Franceschi. 2007. Correlations between calcium oxalate crystals and photosynthetic activities in palisade cells of shade-adapted Peperomia glabella. Botanical Studies (Taipei, Taiwan) 48: 155-164.

Leliaert, F., and E. Coppejans. 2004. Crystalline cell inclusions: A new diagnostic character in the Cladophorophyceae (Chlorophyta). Phycologia 43: 189-203.

Lersten, N. R., And H. T. Horner. 2000. Calcium oxalate crystal types and trends in their distribution patterns in leaves of Prunus (Rosaceae: Prunoideae). Plant Systematics and Evolution 224: 83-96.

Lersten, N. R., AND H. T. Horner. 2004. Calcium oxalate crystal macropattern development during Prunus virginiana leaf growth. Canadian Journal of Botany 82: 1800-1808.

LeRSTEN, N. R., AND H. T. Horner. 2005a. Development of the calcium oxalate crystal macropattern in pomegranate (Punica granatum, Punicaceae). American Journal of Botany 92: 1935-1941.

Lersten, N. R., AND H. T. Horner. 2005b. Macropattern of styloid and druse crystals in Quillaja (Quillajaceae) bark and leaves. International Journal of Plant Sciences 166: 705-711.

Lersten, N. R., and H. T. Horner. 2006. Crystal macropattern development in Prunus serotina (Rosaceae; Prunoideae) leaves. Annals of Botany 97: 723-729.

Lersten, N. R., And H. T. Horner. 2007. Calcium oxalate crystals in tribe Galegeae (Leguminosae) including foliar crystal macropattern development in Caragana frutex. Canadian Journal of Botany 85: 394-403.

Lersten, N. R., and H. T. Horner. 2008a. Crystal macropatterns in leaves of Fagaceae and Nothofagaceae: A comparative study. Plant Systematics and Evolution 271: 239-253.

Lersten, N. R., and H. T. Horner. 2008b. Subepidermal idioblasts and crystal macropattern in leaves of Ticodendron (Ticodendraceae). Plant Systematics and Evolution 276: 255-260.

Lersten, N. R., AND H. T. Horner. 2009. Crystal diversity and macropatterns in leaves of Oleaceae. Plant Systematics and Evolution 282: 87-102.

Lersten, N. R., AND H. T. Horner. 2011. Unique calcium oxalate "duplex" and "concretion" idioblasts in leaves of tribe Naucleeae (Rubiaceae). American Journal of Botany 98: 1-11.

Maddison, W. P., ANd D. R. MAdDison. 2011. Mesquite: A modular system for evolutionary analysis, version 2.75. Website http:// mesquiteproject.org.

McNaIR, J. B. 1932. The interrelation between substances in plants: Essential oils and resins, cyanogen and oxalate. American Journal of Botany 19: 255-272.

Metcalfe, C. R., and L. Chalk. 1957. Anatomy of the dicotyledons, vol. II, 1120-1122. University Press, Oxford, UK.

Metcalfe, C. R., and L. Chalk. 1983. Anatomy of the dicotyledons, 2nd ed., vol. II, 84-94. Clarendon Press, Oxford, UK.

NaKATA, P. A. 2003. Advances in our understanding of calcium oxalate crystal formation and function in plants. Plant Science 164: 901-909.

Nakata, P. A., And M. M. McConn. 2007. Genetic evidence for differences in the pathways of druse and prismatic calcium oxalate formation in Medicago truncatula. Functional Plant Biology 34: 332-338.

OlsEN, C. 1939. Absorption of calcium and formation of oxalic acid in higher green plants. Comptes-Rendus, des Travaux du Laboratoire Carlsberg. Chimiques 23: 101-124.

Poirault, G. 1893. L'oxalate de calcium chez les Cryptogrames vasculaires. Le Journal de Botanique VII: 72-75.

Pueschel, C. M. 2001. Calcium oxalate crystals in the green alga Spirogyra hatillensis (Zygnematales, Chlorophyta). International Journal of Plant Sciences 162: 1337-1345.

Pueschel, C. M., AND J. A. West. 2007. Cytoplasmic streaming of calcium oxalate crystals in Callipsygma wilsonis (Bryopsidales, Chlorophyta). Phycological Research 55: 278-285.

Samain, M.-S., L. Vanderschaeve, P. Chaerle, P. Goetghebeur, C. Neinhuis, And S. Wanke. 2009. Is morphology telling the truth about the evolution of the species rich genus Peperomia (Piperaceae)? Plant Systematics and Evolution 278: 1-21 (erratum, 280: 251-254). 
SCHÜRHOFF, P. 1908. Ölzellen und Lichtkondensoren bei einigen Peperomien. Beihefte zum Botanischen Zentralblatt 23: 14-26.

Souza, L. A., I. S. Moscheta, and J. H. G. Oliveira. 2004. Comparative morphology and anatomy of the leaf and stem of Peperomia dahlstedtii C. DC., Ottonia martiana MIQ. and Piper diospyrifolium Kunth (Piperaceae). Gayana Botánica 61: 6-17.

WAGNER, B. L. 1983. Genesis of the vacuolar apparatus responsible for druse formation in Capsicum annuum L. (Solanaceae) anthers. Scanning Electron Microscopy 2: 905-912.
Williams, K., C. B. Field, AND H. A. Mooney. 1989. Relationships among leaf construction cost, leaf longevity, and light environment in rain-forest plants of the genus Piper. American Naturalist 133: 198-211.

ZiNDLER-FrANK, E. 1976. Oxalate biosynthesis in relation to photosynthetic pathway and plant productivity-A survey. Zeitschrift für Pflanzenphysiologie 80: 1-13.

Zindler-Frank, E. 1987. Calcium oxalate crystals in legumes. In C. H. Stirton [ed.], Advances in legume systematics, part 3, 279-316. Royal Botanic Gardens, Kew, UK.

APPENDIX 1. Voucher information for the 63 Piper species used in this study (10 species have two collections and two species have three collections). Underlined species (41 total) are included in the phylogenetic tree (Fig. 38). Herbaria: DUKE, Duke University; F, Chicago Natural History Museum; ISC, Iowa State University; and MO, Missouri Botanical Garden.

Taxon, Voucher, Date collected, Country [Herbarium].

P. aduncum L., A. Bornstein \& F. Coe 965, Guatemala, 20 VI 2005, [MO]; P. aduncum L., R.L. Wilbur \& K. Williams 66684, Costa Rica, 11 III 1997 , [MO]; P.amalago L., M. Nee 48731, Bolivia, 21 III 1998, [MO]; . amalago L., J. Campos \& P. Diaz 2953, Peru, 14 VII 1996, [MO]; P. arborescens Roxb var. angustilimbum Quisumb., M. A. Jaramillo, R. Callejas, F. Gaerlan, \& E. Reynoso 192, Philippines, 22 V 1999, [DUKE] 369895; P. arboreum Aubl., Steve Hollis, Manuel Rimachi Y. \& Sidney McDaniel 32861, Peru, 15 III 1995, [MO]; 4a. P. arboreum Aubl., S.S. Tillett 737-112, Venezuela, 21-22 VII 1973 [MO]; P. archeri Trel. \& Yunck., L. Albert de Escobar, F.J. Roldan \& J. Betancur B. 7503, Colombia, 31 III 1987, ]MO]; P. arieianum C.DC., A. Gentry \& L.E. Aguirre 15282, Colombia, 17 VII 1975, [MO]; P. augustum Rudge, D.D. Soejarto 2677, Colombia, 9 II 1971 [MO]; P. augustum Rudge, A. Gentry, F. Ayala, Diaz \& N. Jaramillo 21,748, Peru, 12 V 1978, [MO]; P. auritum Kunth, G. McPherson 13357, Colombia, 1 XII 1988 [MO]; P. auritum Kunth, J.M. MacDougal, P. House \& R. Zuniga 3216, Honduras, 6 XI 1988, [MO]; P. bartlingianum (Miq.) C.DC., G. Davidse, O. Huber \& S.S. Tillett 17,121, Venezuela, $3 \mathrm{~V}$

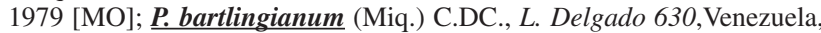
IX 1989, [MO]; P. bavinum C.DC., C. Shaoqing 12372, Asia, X 1995 [MO]; P. berlandieri C.DC., C.G. Pringle 3751, Mexico, 12 VI 1891, [ISC] 39174; P. berlandieri C.DC., C.G. Pringle 6828, Mexico, 1 V 1898, [ISC] 39173; P. betle L., N.H. Li 117, China, 11 VII 1993, [MO]; P. boehmeriifolium Wall., Wen Bin 990740, Asia, 13 VII 1999 [MO]; P. caninum Blume, M. A. Jaramillo, R. Callejas, F. Gaerlan, \& E. Reynoso 218, Philippines, 27 V 1999, [DUKE] 369867 P. cavendishioides Trel. \& Yunck., D. Rubio, C. Quelal \& C. Pai 1113, Ecuador, 16-26 III 1991, [MO]; P. celtidiforme Opiz, M. A. Jaramillo, R. Callejas, F. Gaerlan, \& E. Reynoso 190, Philippines, 21 V 1999, [DUKE] 369884; P. chrysostachyum C. DC., R.L. Liesner 62, Panama, 18 II 1973, [ISC] 332793; P. cinereum C. DC., R. Fonnegra, J. Betancur, F.J. Roldan, B. Echeverry \& O. Escobar 1676, Colombia, 3 III 1987, [MO]; P. cinereum C. DC., A. Gentry \& M. Fallen 17207, Colombia, 4 VIII 1976, [ISC] 347291; P. confertinodum (Trel. \& Yunck.) M.A. Jaram. \& Callejas, M. A. Jaramillo, R. Callejas, F. Alzate, \& F. Cardona 636, Colombia, 8 VII 2000, [DUKE] 386063 P. confusum C. DC., H. von Turckheim 3298, Santo Domingo, 1910, [ISC] 51314; P. darienense C. DC., D. Cardenas 1632, Colombia, 14 IV 1988, [MO]; P. decumanum L., M. A. Jaramillo, R. Callejas, F. Gaerlan, \& E. Reynoso 210, Philippines, 26 V 1999, [DUKE] 369873; P. dotanum Trel., R.O. Lawton 1131, Costa Rica, 16 I 1977, [ISC] 343092; P. eriopodon (Miq.) C. DC., H.H. Smith 1228, Colombia, 1898-1901, [ISC] 236797; P. excelsum G. Forst., E. L. Girardi SN, New Zealand, 31 I 1983 , [F] 2283458; P. filistilum C. DC., J. L. Clark, B. Adnepos \& J. Wolf 125, Ecuador, 27 IX 1994, [MO]; P. flagellicuspe Trel. \& Yunck., T.B. Croat 57418, Colombia, 13 III 1984, [MO]; P. garagaranum C. DC., L. Angulo 596, Costa Rica, 14 IV 1996, [MO]; P. glabrescens C.DC., R. W. Lent 2709, Costa Rica, 9 VII 1972, [ISC] 332018; P. hispidum Sw., J. Morales, R. Avila, \& J. Gar 2795, Guatemala, 11 X 2004, [MO]; P.hispidum Sw., Rolando Tun Ortiz 2159, Guatemala, 7 I 1972, [ISC] 330426; P. hispidum Sw., M. A. Jaramillo, R. Callejas, F. Alzate, \& F. Cardona 611, Colombia, VII 7 2000, [DUKE] 390341; P.jacquemontianum Kunth, R. Tun Ortiz 1925, Guatemala, 13 IX 1971, [ISC] 330427; P. jalapense
M. Martens \& Galeotti, C.G. Pringle 8074, Mexico, 3 IV 1899, [ISC] 39175; P. jaliscanum S.W. Watson, C.G. Pringle 3871, Mexico, 1 X 1891, [ISC] 39176; P. korthalsii Miq., M. A. Jaramillo, R. Callejas, F. Gaerlan, \& E. Reynoso 184, Philippines, V 21 1999, [DUKE] 369880; P. lapathifolium Steud., C.G. Pringle 8067, Mexico, 3 IV 1899, [ISC] 39177; P. ledebourii C.DC., H. von Turckheim 3237, Dominican Republic, 1910, [ISC] 79287; P. leucophyllum (Miq.) C.DC., C.G. Pringle 6824, Mexico, 10 V 1898, [ISC] 39180; P. leucophyllum (Miq.) C.DC., C.G. Pringle 7128, Mexico, 17 VI 1896, [ISC] 39178; P. leucophyllum (Miq.) C. DC., C.G. Pringle 3885, M. A. Jaramillo, R. Callejas, F. Gaerlan, \& E. Reynoso 213, Philippines, 27 V 1999, [DUKE] 369875. P. marginatum Jacq., E.R. Heithaus 342, Costa Rica, 1 IX 1971, [ISC] 326213; P. martensianum C. DC., J. Rzedowski 23105, Mexico, 15 IX 1966, [ISC] 260121; P. medium Jacq., H. von Turckheim 2840, Dominican Republic, 1909, [ISC] 70615; P. methysticum G. Forst., R.W. Pohl 9331, Florida, VII 1960, [ISC] 238593; P. michelianum CDC, specimen not available; P. multiplinervium C. DC., M.D. Correa, R.L. Dressler, N. Esobar \& L. Carrasquilla 1810, Panama, 25 VIII 1972, [MO]; P. multiplinervium C. DC., A. Gentry \& M. Fallen 17614, Colombia, 13 VIII 1976, [MO]; P. munchanum C. DC., M.O. Dillon, I. Sanches V, \& J. Guevara B. 6153, Peru, 4 XI 1990, [MO]; P. nemorense C. DC., R.W. Lent 25, Costa Rica, 7 VII 1964, [ISC] 342815; P. nigrum L., F.R. Fosberg 50649, Ceylon, 18 XII 1968, [MO]; P. oxystachyum C. DC., T.B. Croat 72365, Ecuador, 22 II 1992, [MO]; P. pansamalanum C. DC., L. Gonzalez Quintero 686, Mexico, 26 III 1964, [ISC] 2540?; P.peltatum L., M.A. Baker 5975, Ecuador, 10 IV 1985, [MO]; P.peltatum L., A. Arauho-M., A. Antezana, F. Miranda, A. Poma \& N. Flores 807, Bolivia, 30 V 2004, [MO]; P. penninerve C.DC., M.A. Jaramillo, R. Callejas, F. Gaerlan, \& E. Reynoso 213, Philippines, V 271999 , [DUKE] 36987529. P. pierrei C.DC., specimen not available; P. pseudofuligineum C.DC., D.M. Porter, J.D. Dwyer, L.H. Durkee, M.R. Crosby, \& J.R. Castillion 4988, Panama, 1 IV 1969, [ISC] 332790; P. pseudovariabile Trel., A. Gentry \& M. Nee 8678, Panama, 5 XII 1973, [ISC] 347285; P. psilorachis C.DC., R. Tun Ortiz 2705, Guatemala, 15

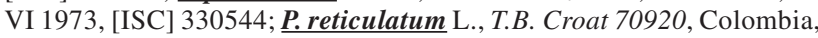
23 II 1990, [MO]; P. reticulatum L., T.B. Croat 69871, Panama, 20 I 1990, [MO]; P. purpurascens D. Dietr., $R$. Combs 8, Cuba, 2 V 1895, [ISC] 111378; P. retrofractum Vahl., D.D. Soejarto, O Fernando \& E. Reynoso 7666, Philippines, F 2112631; $\underline{\text { P. sanctifelicis Trel., J. Revilla }}$ \& C.H. Froehner 2436, Peru, 9 V 1977, [ISC] 347341; P. sanctifelicis Trel., A. Gentry \& M. Nee 8677, Panama, 5 XII 1973, [ISC] 347347; P. scalarispicum Trel., L.O. Williams, A. Molina R., \& T. P. Williams 24926, Nicaragua, II 1963, [ISC] 329598; P. subpedale Trel. \& Yunck., F.J. Roldan, N. Lopez \& A. Arango 3942, Colombia, 8 VII 2004, [MO]; P. swartzianum C. DC., H. von Turckheim 24747 ,

Dominican Republic, 1909, [ISC] 70569; $\underline{\text { P. umbellatum L., C.G. Pringle }}$ 6159, Mexico, 12 XI 1895, [ISC] 39183; P. urdanetanum C.DC., M.A Jaramillo, R. Callejas, F. Gaerlan, E. Reynoso, G. Anton, A. Silakay \& M. Cembrano 232, Philippines, 30 V 1999, [MO]; P. unguiculatum Ruiz. \& Pav., C.G. Pringle 8075, Mexico, 3 IV 1899, [ISC] 39184 
APPENDIX 2. Summary of information for 41 Peperomia species (clades according to Samain et al. [2009] in parentheses) not included in Horner et al. (2009) that extend this latter survey. All specimens are from herbarium sheets obtained from the Botanical Garden deposited in the Gent Herbarium at the Ghent University [accession number]. The crystal macropatterns from these species are shown in Table 3.

Taxon (Clade), Voucher, [accession]

P. albonervosa Mathieu (Tildenia), Samain et al. 2007-039, [20071221]; $\boldsymbol{P}$. andina Pino (Tildenia), Mathieu et al. 2009-010, [20090833]; P. asarifolia Schltdl. \& Cham. (Oxyrhynchum), Samain et al. 2007-078, [20071263]; P. ayacuchoana Pino \& Samain (Tildenia), Samain et al. 2009-040, [20090674]; P. bracteata A.W. Hill (Tildenia), Samain et al. 2009-264 [20091474], ; P. cardenasii Trel. aff. (unnamed B), Samain et al. 2009-238, [20090821]; P. crystallina Ruiz \& Pav. (Micropiper), Samain 2012-025, [19004095]; P. curticaulis Trel. (unnamed E), Samain et al. 2010-078, [2010-078]; P. distachya (L.) A. Dietr. (Leptorhynchum), Samain et al. 2009-231, [20090814]; P. dolabriformis var. grandis Hutchison ex Pino \& Klopfenstein (Panicularia), Pino 1492, [20070832]; P. dolabriformis var. grandis Hutchison ex Pino \& Klopfenstein (Panicularia), Mathieu et al. 112, [2009-0560]; P. exclamationis Mathieu (Tildenia), Samain et al. 2007045, [20071227]; P. inaequalifolia Ruiz \& Pav. (), TM 207, [20070780]; Peperomia sp. (Panicularia), Samain et al. 2007-050, [20071232]; P. macrandra C.DC. aff. (Tildenia), Samain et al. 2007-032, [20071214]; $\boldsymbol{P}$. macrorhiza Kunth (Tildenia), RRP 243, [20101074]; P. monticola Miq. (Tildenia), Samain et al. 2007-032; P. nitida Dahlst. aff. (Leptorhynchum), Samain 2012-026, [20090812]; P. nivalis Miq. (Panicularia), Maijer 277, [20070846]; P. peltigera C.DC. (unnamed E), Samain 2012-027, [20032025]; P. pereskiifolia (Jacq.) Kunth (unnamed B), Symmank et al.
2008-078, [20080309]; P. polzii Rauh ex Bogner (Micropiper), Samain et al. 2010-073, [20101060]; P. procumbens C.DC. (unnamed E), Samain et al. 2009-228, [20090811]; P. pseudoperuviana (Pino) Pino (Tildenia), Pino 298, [20081099]; P. pseudoumbilicata Yunck. (unnamed E), Samain et al. 2008-119, [20080292]; P. rupiseda C.DC. (Tildenia), Mathieu et al. 2009-032, [20090486]; P. schizandra Trel. (Tildenia), Martínez S. 40636, [20091481]; P. schunkeana Trel. (Leptorhynchum), Samain 2012028, [20021922]; P. sodiroi C.DC. aff. (unnamed E), Samain 2012-029, [20032008]; P. species (new clade), Samain et al. 2009-160, [20090745]; P. species (Panicularia), Mathieu et al. 2009-069, [20090520]; P. steinbachii Yunck. (Micropiper), Symmank et al. 2008-070, [20080364]; P. strawii Hutchison ex Pino \& Klopfenstein (Panicularia), Maijer 281, [20070829]; P. subblanda C.DC. (Micropiper), Samain et al. 2007-111, [SSM 2007-111]; P. tetragona Ruiz \& Pav. (unnamed B), Samain et al. 2009-198, [20090781]; P. trinervis Ruiz \& Pav. (Micropiper), Samain et al. 2009-180, [20090763]; P. urocarpa Fisch. \& Mey. (Leptorhynchum), [2009171]; P. verruculosa Dahlst. ex Hill (Tildenia), Samain et al. 2010083, [20101071]; P. vestita var. lindenii Rauh (Leptorhynchum), Samain 2012-030, [20031696]; P. wernerrauhii Pino \& Samain (Tildenia), Samain et al. 2009-214, [20090797]; P. wolfgang-krahnii Rauh (Panicularia), Mathieu et al. 2009-029, [20090484]. 